\title{
THE CHANGES IN SOCIAL AND DEMOGRAPHIC STRUCTURE OF LARGE HOUSING ESTATES IN POST- -SOCIALIST POLAND AND THEIR MAIN DETERMINANTS
}

\begin{abstract}
Large pre-fabricated housing estates were erected all over Europe, however the political and ideological factors conspired to ensure that they developed on the largest scale in communist countries. Today, they continue to provide some $30-40 \%$ of the housing stock in this part of Europe. The present paper discusses the transformations of large housing estates in Poland 25 years after of the collapse of communism. The main purpose of the study was to identify the social and demographic changes in Polish large housing estates and to clarify the crucial factors underpinning them. The key questions were: (1) How the social and demographic structures of the large housing estates in Poland have changed since the collapse of communism? (2) What are the main determinants of these processes? (3) Whether the processes occurring in large housing estates reproduce the negative phenomena of social degradation observed in many Western European countries? The study is based on a review of the available literature concerning transformations of large housing estates in several of the large Polish cities and the results of the author's own investigations conducted within Łódź - one of the largest cities in the country.
\end{abstract}

Keywords: Large housing estates, post-socialist city, social and demographic changes, CEE countries, Poland.

\section{Introduction}

As Frank Wassenberg rightly pointed out in his book Large Housing Estates: Ideas, Rise, Fall and Recovery (2013) large housing estates for many people symbolise all that is wrong in urban planning. Large is wrong, because a lot of people prefer a living surrounding that reflects the human scale. Housing is wrong, because lively and vital urban areas should not be mono-functional but be a mix of functions that create activities, vital use and practical contacts between people. Estates are wrong, as people do not live within a particular area that is developed for them but without them (Wassenberg 2013). In conclusion, the author states that large housing estates, especially high rise blocks, are very symbolic outcomes of the way a city should not be planned. 
However, it is not enough to state that large housing estates have been planned the wrong way. They are inhabited by millions of people all across Europe and because of their scale they constitute a real challenge for many European urban areas.

The idea according to which these estates were built, i.e., that of improving the living conditions of the working class through the construction of modern housing estates, emerged in the early $20^{\text {th }}$ century. However, the principal period of construction of the large housing estates started after the Second World War. Then, a severe shortage of dwellings combined with the rapid post-War growth in population and the increasing pace of urbanisation made housing estates a viable and widespread solution that could offer homes to a very large of people in need, for a relatively cheap price (Dekker et al. 2005: 2).

Although large housing estates were erected all over Europe, it can not be forgotten that political and ideological factors conspired to ensure that they developed on the largest scale in state-socialist countries. Today, they continue to provide some $20-40 \%$ of the housing stock in this part of Europe, while in Western European countries, the percentage share of all housing resources accounted for by these estates is an estimated 3-7\% (Kovács, Herfert 2012). In Poland they constituted about $35 \%$ of the whole residential housing stock (Rębowska 2000).

In Poland, as in other communist countries, the large housing estates were seen as instruments of social transformation and an improvement in living conditions, especially for the working class (Węcławowicz et al. 2005). Moreover, the idea of collective and uniform housing was perfectly fitted to state-socialist politics and made it possible to achieve the ideological goal which was a mix of different social groups, in accordance with the idea of egalitarianism (Sagan 2000; Kovács, Herfert 2012). It also fitted to another important goal of this policy that was to equalize the housing conditions within the urban space. Hence the era of the construction of large housing estates in CEE countries lasted until the end of the 80 's, i.e., to the collapse of socialism, while in most Western European countries it ended almost two decades earlier.

During the state-socialist era, these residential complexes were built hastily and negligently in order to satisfy growing residential needs caused by accelerating urbanization. Their main drawbacks were: monotonous architecture, poor technical quality of large-panel buildings inflexible design systems, substandard floor plans (small rooms, kitchens without windows, or dysfunctional bathrooms) and small floor areas, as well as the insufficient social infrastructure and the shortage of basic services.

However, despite these characteristics, the large housing estates were seen as an attractive place of residence during the socialist period. This resulted from the fact that moving to a new block of flats in a new housing estate, was usually the only chance to improve one's living conditions socialist cities (Węcławowicz 2007). A structural deficit on the housing market, created a reality in which residing in a block of flats was a dream for the majority of socialist cities' inhabitants, 
regardless of their social status (Lewicka 2004). This made the social structure of these estates heterogeneous and the prestige associated with living there was relatively high (Szelenyi 1996). Unlike in most Western European countries, they were home for not only lower social classes (Musterd, van Kempen 2005), but also for the socialist middle class and even for representatives of socialist elites (Éróss 2013).

The collapse of communism initiated intensive social and spatial changes of the large prefabricated housing estates and of other urban areas. Their appearance and social perception are also changing (Szafrańska 2014). The emergence of more attractive housing areas in the city (suburbs, gated communities, new apartment buildings) lowered the prestige of these estates (Kovács, Herfert 2012). In the 1990s some authors predicted that prefabricated socialist housing estates, by the same token as in West European countries, would soon become problem areas and turn into post-socialist slums (see Jałowiecki 1995; Szelényi 1996; Enyedi 1998; Czepczyński 1999; Rykiel 1999).

Recently the discussion of social and physical decay and the outflow of better-off inhabitants has slowed down (Wiest 2011; Gorczyca 2016; Szafrańska 2016) however, the future development of large housing estates still remains a great challenge in many former socialist countries, primarily due to the fact that they constitute the dominant form of urban residential environment.

\section{Objectives and research materials}

The main purpose of this study was to present the social and demographic changes in large housing estates in post-socialist Poland and to clarify the crucial factors underpinning them. The key questions were: (1) how the social and demographic structures of the large housing estates in Poland have changed since the collapse of communism? (2) what are the main determinants of these processes? (3) whether the processes occurring in large housing estates in post-socialist Poland reproduce the negative phenomena of social and physical degradation, in the literature referred as the "large housing estate syndrome" (Rembarz 2010) or "spiral of decline" (Prak, Priemus 1986)?

The "large housing estate syndrome" was a phenomenon recognized in Western Europe in the 1980s and defined as a complex of spatial-social conditions, producing a negative image of an estate and accelerating the downward spiral and the replacement of the culturally stronger inhabitants by weaker ones. It leads to an increase in the number of vacant flats and structural social problems, intensifying the spatial degradation. This in turn causes the economic potential of the estate (such as the purchasing power or the market value of the housing resources) to disappear (Rembarz 2010). The "spiral of decline" may be increased because more stable and affluent households move away or because there are no opportunities for deprived households to move away (Prak, Premius 1986). 
The study was based on a review of the available literature concerning large housing estates in post-socialist Polish cities and the results of the author's own investigations conducted in the second large Polish city (Łódź), published in 2014 and 2016.

\section{The development of LHE in state-socialist Poland}

Similarly to other CEE countries, the era of building large housing estates began in Poland in the late 1950s, and lasted until the early 1990s. That period, which lasted almost 40 years, can be divided into several stages as regards the development of this form of building (see Kiciński 2004; Tokajuk 2007; Wojtkun 2008): 19561964, 1965-1970, 1971-1980 and 1980-1989. Despite the differences between the housing estates built during individual stages, the standards imposed by central authorities (building and urban planning standards) made them similar in many respects. Due to the political system factors, the estates were built exclusively by the public sector. Starting from 1956, there were three main investors in Poland: the state, state enterprises and the reactivated housing cooperatives. However, the reactivation of the housing cooperatives, whose traditions went back to the pre-war times in Poland, was only illusory, because they were actually "para-state" bodies, dependent on the centrally controlled housing policy (Basista 2001). From the beginning of the $1970 \mathrm{~s}$, the housing cooperatives dominated the construction of large housing estates in Poland.

The housing estates built during the first period (1956-1964) were relatively small. Their design drew from the conceptions of a C.A Perry's neighborhood unit and E. Howard's vision of garden-city, as well as the architectonic and urban planning solutions adopted at this time in Sweden and Great Britain (Kiciński 2004). Until the early 1960s, buildings in housing estates had been erected using mixed technology, i.e. traditional materials (brick) combined, in a small part, with prefabricated elements. The estates were often located within a close distance from the compact urban fabric of the city centre. Due to their relatively well developed system of basic services and green areas, they provided their inhabitants with fairly good living standard. Unfortunately, from the beginning of the 1960s, as a result of implementing the austerity policy, the living conditions in the newly built housing estates started to deteriorate. In 1961, the standard living area was limited to $5-7 \mathrm{~m}^{2}$ per person ${ }^{1}$ (which was clearly regressive compared to the earlier years), constructing lower than 5-storey buildings was forbidden and the scope of the service facilities program was reduced (Basista 2001; Wojtkun 2008).

\footnotetext{
${ }^{1}$ This limitation resulted from the housing norm regulating the allocation of flats, and was regarded as a temporary solution, but practically it was in effect until 1971. The regulations allowed putting three people in an M-2 category flat, four or even five in an M-3 flat, and even six in an M-4 flat, which seriously exceeded the formally established housing standards (Tokajuk 2007).
} 
In the mid-1960s, housing estates built as part of the austerity policy started to be put into service (Basista 2001), which resulted in a lower standard of the flats. The number of high-rise buildings increased considerably (they were usually 11-storey structures) and, in order to reduce the construction costs, so called „corridor” buildings were introduced, with flats overlooking one side only, which substantially worsened their usability. Concrete started to be used on a mass scale, which resulted in the worsening of the thermal and acoustic insulation of flats (Tokajuk 2007). More and more often, the idea of building balconies and loggias was abandoned, the rules of proper flat layout design was ignored for the benefit of enfilade solutions, and appropriate proportions in flats were not kept.

The principle of austerity led to building flats with kitchens without windows, devoid of day light. This idea, however, was abandoned after a few years due to strong social protests. Buildings started to be constructed almost solely from concrete prefabricated elements, which caused unification and lack of individuality of buildings in individual housing estates, as well as of whole estates. New regulations prohibited implementing individual designs and erecting lower than 5-storey (low-rise) or 11-storey (high-rise) buildings, as those heights were regarded as the most economical (Basista 2001). The most important thing was to build flats fast, which involved limitations and delays in the construction of service, recreation, sports facilities and parking lots. The housing estates designed between 1965-1970 were built further and further from density urban fabric and from city centres and covered increasingly large areas (Tokajuk 2007).

The next stage in the development of housing estates in Poland began in 1971 and lasted until 1980. The regulations concerning housing construction (which were formally changed only in 1974), had undergone certain changes already in the early 1970s (Tokajuk 2007). According to the new housing standards, the average size of flats increased considerably, their functional structure improved (e.g. the bathroom was separated from the toilet, the flats had to have balconies or loggias), and the flat layout was modified (a separate door lead to each room). The changes introduced in 1974 also raised the standards of the housing estate infrastructure. They included increasing the minimal greenery and recreational area per one inhabitant (to $8 \mathrm{~m}^{2}$ and $5.5 \mathrm{~m}^{2}$, respectively), increasing the number of parking places and plans to increase the service area by $50 \%$. The solar insolation of flats increased and it became allowed to erect buildings of varying height (2-16 storeys), though in practice, 5 - and 11-storey buildings were still predominant (Basista 2001). A characteristic feature of this period was the predominance of concrete panel construction, which became an increasingly popular form of housing resources (at the end of the 1960s - it made up around 16\%, while in 1980 - almost $85 \%$ of the living area in multi-family housing in cities). The concrete panel construction was characterized by even stronger unification and standardization (both, of flats and whole buildings). It was impossible to change the flat layout or adjust the flats to the inhabitants' individual needs. The buildings 
also had many faults coming out at the production stage (in house factories), during transport to the building site and at the assembly stage, which significantly lowered the quality of the finished flats (Rębowska et al. 2006). The 1970s were characterized by the most dynamic increase in the number of flats in large housing estates after World War II. It was when the largest Polish estates were built, accommodating several dozen, or even over 100,000 inhabitants (e.g. Ursynów in Warsaw). They were erected far from the compact buildings in the city centre and became huge, mono-functional "mega dormitories" of socialist cities.

From the beginning of the 1980 s, as a result of the economic crisis, the scale of housing investments started to decrease. The number of new flats per 1000 people, in 1986-1990 was nearly two times lower than at the peak of the 1976-1980 phase (Jarosz 2010).

Until the mid-1980s, the attempts to make savings resulted in a worsening condition of the housing estate infrastructure, including service facilities and green areas, as well as in a lower standard of new flats. In the second half of the $1980 \mathrm{~s}$, towards the end of the socialist era, the situation slightly improved. The new estates started to include modest architectonic details in the form of more decorative entrance doors to the buildings, balconies, small, steep roofing elements etc. The buildings were also more varied as regarded their height, and the designers took the need of creating public spaces in housing estates into account (Nowakowski 2013). The average size of the flats put into use increased, and after the future inhabitants' needs had been taken into more serious consideration, the housing estates from that period became most attractive in Polish cities (Kiciński 2004).

In 1989, at the beginning of the political and economic system transformation, the state withdrew from housing construction administration, which put an end to the building of large housing estates. The last of them were being slowly finished still in the early $1990 \mathrm{~s}^{2}$. The total number of flats put into use between the end of World War II and the mid-1990s in Polish cities was 5.7 million, over 3.5 million of which were flats built using prefabricated technology, typical of huge housing estates (Rębowska et al. 2006) - Table 1.

In result of their massive development, the large housing estates constituted a significant part of the housing market in former socialist countries. In post-socialist Poland, in the mid of the1990s, various estimates state that more than 8 million people were residing in large housing estates (Węcławowicz 2007), with these, thereby, accounting for over $50 \%$ of the urban population (Rębowska 2000 ), and about $56 \%$ of urban households (Rembarz 2010). In Warsaw, it was

\footnotetext{
${ }^{2}$ In order to complete housing investments, co-operatives, which were unable to obtain bank credits, required the future tenants to participate in the cost of building the flats, which in many cases was impossible.
} 
600,000 of 1,671,700 inhabitants, and in Kraków 150,000 of 758,500 inhabitants (Węcławowicz et al. 2003). In the third largest Polish city - Łódź (City of Lodz) - the estimated number of inhabitants in these housing areas was over 300,000 of 798,000 in the first decade of 21st c. (Szafrańska 2014).

Table 1. Number of housing units in Polish cities built from 1945 to 1995

\begin{tabular}{|c|c|c|c|c|c|}
\hline & \multirow{2}{*}{ Total } & \multicolumn{4}{|c|}{ In individual periods } \\
\hline & & 1945-1970 & 1971-197 & 1979-198 & 1989-1995 \\
\hline $\begin{array}{l}\text { Number of housing units } \\
\text { (in thousands) }\end{array}$ & 5718,1 & 2012,4 & 1566,7 & 1585,5 & 553,5 \\
\hline $\begin{array}{l}\text { - in that built with } \\
\text { prefabricated technology }\end{array}$ & 3573,1 & 461,1 & 1262,8 & 1445,4 & 403,8 \\
\hline $\begin{array}{l}\text { Usable floor area } \\
\text { (in } \mathrm{mln} \text { of } \mathrm{m}^{2} \text { ) }\end{array}$ & 334,9 & 102,8 & 85,6 & 104,1 & 42,4 \\
\hline $\begin{array}{l}\text { - in that built with } \\
\text { prefabricated technology }\end{array}$ & 218,2 & 23,6 & 69,0 & 94,9 & 30,8 \\
\hline
\end{tabular}

Source: own elaboration on estimations made by A. Rębowska et al. (2006)

\section{Large housing estates in Poland within the European context}

Unlike in certain European countries, there is no single definition of large housing estates in Poland ${ }^{3}$, hence numerous authors (e.g. Węcławowicz et al. 2005; Górczyńska 2008; Gorczyca 2009) use the definition formulated for the purposes of the RESTATE ${ }^{4}$ project. According to this definition, large housing estates constitute spatially isolated groups of buildings, comprising over 2000 flats, built in the second half of the $20^{\text {th }}$ century, planned and fully or partly financed by the state 5 .

${ }^{3}$ In several European countries, the definition of a large housing estate is a specific legal category introduced in order to facilitate the pursuit of a spatial policy oriented towards transforming these areas and preventing the large housing estate "syndrome". In Germany, the legal category of Großsiedlung takes in estates with at least 2500 flats (Wassenberg et al. 2004), while in France, Grand Ensemble status is assigned to housing areas with over 2000 flats within Greater Paris, or else over 1000 flats where the outskirts of are concerned (Coudroy de Lille 2000; Rembarz 2010).

${ }^{4}$ RESTATE - the acronym of the international research project ,Restructuring Large-scale Housing Estates in European Cities: Good Practices and New Visions for Sustainable Neighbourhoods and Cities", 2005.

${ }^{5}$ According to other European authors, large housing estates are defined as residential complexes constructed using prefabricated technology with over 2500 housing units (Knorr-Siedow 1996) or over 6000 (Wiest 2011; Kovács, Herfert 2012). 
Despite their similar physiognomy, the large housing estates built in Poland (likewise in other CEE countries) were different from those found in Western Europe. They differed primarily in terms of the urban planning scale and the role played on the local housing market, the time of construction, the dominant form of ownership, and the socioeconomic status of inhabitants - and consequently their residential prestige and position in the ecological structure of the city in which they were located (Coudroy de Lille 2000; Musterd, van Kempen 2005; Węcławowicz 2007; Sýkora 2009; Kovács, Herfert 2012; Szafrańska 2014, 2015).

The first and most fundamental difference concerns the „weight” of large housing estates on the domestic housing market. In Poland, as of the 1990s, the different estimates have it that more than 8 million people were resident in large housing estates (Węclawowicz 2007), with these thereby accounting for over $50 \%$ of the urban population (Rębowska et al. 2006), and about $56 \%$ of urban households (Rembarz 2010). In Warsaw it was 600,000 of 1,671,700 inhabitants, and in Kraków 150,000 of 758,500 inhabitants (Węcławowicz et al. 2003). In third largest Polish city - Łódź the estimated number of inhabitants of this housing areas was over 300,000 of 798,000 (Szafrańska 2013).

Putting together the number of flats in large housing estates and the number of all flats built from 1960 to 1990 in Poland, as well as the overall number of flats, their shares are respectively $61 \%$ and $35 \%$. Thus, they are one of the highest in Europe, only lower than in the former Czechoslovakia (66\% and 36\% respectively - Knorr-Siedow 1996).

Differences between countries on the both side of Iron Curtain also affected the construction periods where the large housing estates are concerned. Thus, the peak of the development of this particular urban form in Poland (similarly to the majority of state-socialist countries) was recorded in the 1970s (only in Hungary and Slovenia in the 1980s), and lasted until the early 1990. In the Western Europe countries, in contrast, the idea of building large estates was abandoned in the $1970 \mathrm{~s}^{6}$, following the recognition of these estates as problem areas (Wassenberg et al. 2004).

The next difference between Western and East-Central part of Europe, and also within the bloc of state-socialist countries, was the forms of ownership of flats in large housing estates. In Poland the most of them (on average almost $80 \%$ ) were owned by housing cooperatives. Creating cooperatives was an idea born in Poland before the Second World War. The communists suspended this idea in 1948 and came back to large housing estates in 1956. The cooperatives were supposed to build the dwellings for their members. Since 1972 some of the

\footnotetext{
${ }^{6}$ The symbolic date of the fall of the modernist philosophy behind the idea of block estates is 1972, when the Pruitt-Igoe Estate in the USA, consisting of a complex of 14-storey buildings, was demolished, after it had turned into a crime nest thanks to a lack of people willing to settle there (Jencks 1987).
} 
members of the cooperatives were able to buy out their flats (Węcławowicz et al. 2003). However, these flats were a particular, imperfect type of ownership with a limited right on property (the owner of the building is still the cooperative, which has a right to the land on which the building stands). The percentage shares of the sold flats (with the limited right to property) ranged from $10 \%$ to $40 \%$ in individual estates. Besides the cooperatives, the flats in large housing estates were owned by state-enterprises and the state treasure (at the disposal of the city authorities). In early 1990. their average shares did not exceed respectively $10 \%$ and $15 \%$.

Last essential difference reflects social composition of inhabitants. In CEE countries, the flats in large housing estates were meant for an anonymous group of people, representing medium-level needs (mainly families with children), but they were not the social housing type addressed to the low-income groups. In Poland, similarly to the other state-socialist countries (see Kabisch, Grossmann 2013), they were built for a large segment of the population belonging to a variety of social strata and used as political signs of progress in society, in line with the socialist vision of a homogeneous housing condition. Therefore, the socialist large-block estates were inhabited, not only by blue-collar workers, but also by middle-class families, or even representatives of the socialist elite (Węcławowicz et al. 2003; Zborowski 2005). The social structure of certain of the estates (eg. Ursynów North ${ }^{7}$ in Warsaw, Prądnik Czerwony in Kraków, Radogoszcz-East in Łódź) has been characterized by a relatively high percentage of population with a higher education and representing high-skills professions (Węcławowicz et al. 2003; Zborowski 2005; Szafrańska 2016).

This resulted in the specific ecological position of the large housing estates within the socio-spatial structure of cities in state-socialist countries (Szelényi 1983), which also applies to Polish cities. Unlike in Western European cities, the social status first dropped sharply in certain parts of the densely built-up inner-cities, and then increased again in the zone of housing estates, due to the larger shares of younger and better-educated people (Kovács, Herfert 2012).

Summarizing, most of the large housing estates originating in Poland in the state-socialist period (especially those built in the 1970s, i.e., during the era of their fullest development), were characterised by:

\footnotetext{
${ }^{7}$ According to Węcławowicz and colleagues (2003: 14-15) on the Ursynów North estate (built between 1975 and 1999) "in the 1980s, most of the housing association members were white-collar workers. A big part of the dwellings were (informally) put at the disposal of the city and communist party rulers; plenty of new dwellings were occupied by officials from various ministers. However, it does not mean that the social structure in Ursynów was completely homogeneous. In many blocks of flats the social structure was mixed: for example in one unit a taxi driver lives next to a university professor, or a film director maybe a neighbour of a shop assistant".
} 
- a large urban-planning and demographic scale, frequently exceeding the threshold of 2000 dwellings acknowledged in the literature as the defining criterion;

- construction in the industrial prefabricated (large-panel) technology;

- monotonous architecture and a uniform appearance of buildings;

- a peripheral location in urban space;

- an illegible spatial configuration and spatial anonymity;

- an absence of functional diversification - the housing function was prevalent, while other urban functions were underdeveloped, especially the service function and social infrastructure;

- low workmanship standards and progressing physical (technical) degradation;

- small sizes of dwellings;

- a heterogeneous, mixed community, with a predominance of families with children.

Nevertheless, as has been stated already, the estates were seen as an attractive place to live in socialist cities nonetheless.

\section{The changes in social and demographic structure of large housing estates in post-socialist Poland}

As pointed as numerous authors (Węcławowicz et al. 2003; Zborowski 2005; Gorczyca 2016; Szafrańska 2014, 2016) the most essential processes of social transformations of large housing estates in post-socialist Poland is the ageing of their inhabitants. Characteristically, this processes, observed in all housing estates built in state-socialist period, are synchronised with the time when they were built. This results from the fact that these estates were specifically occupied by a population that was homogeneous in terms of family status (mainly families with children) and age (most frequently, the generation of 30-year-olds at the time). The factors that have enhanced this process over the last 27 years have been, first, the marked residential stability of the original occupants, and, second, a gradual outflow of young inhabitants, as many households enter the stage of the family life cycle called the "empty nest" phase, which starts when adult children leave home (Zborowski 2005). A closer analysis of selected large estates in three Polish cities (Warsaw, Kraków and Łódź) demonstrates that their ageing process, although it progressed rapidly in the 1990 s and the early $21^{\text {st }}$ century, began to slow down with the onset of the 2010s (Węcławowicz et al. 2003; Zborowski 2005; Szafrańska 2014). This ensued from an inflow of people in younger age categories (in their 20s and 30s) into the estates. This is first the outcome of the inheritance of dwellings, which are now occupied by the generation of grandchildren of the original occupants and, second, a reflection of the relatively high rate of sales of these flats on the secondary property market. The research 
in question demonstrates that the occupation of a flat in a prefabricated housing estate represents a frequent first stage in the housing biography of young people only just entering the labour market. This is particularly true of cities in a better economic condition; in other words, large cities and capitals, first and foremost (Węcławowicz et al. 2003).

The slowdown in the rapid pace at which housing estate populations are ageing also reflects an inflow of students, who, for the duration of their studies, rent and sometimes even buy such flats. This process, referred to as "studentification" (Smith 2002), primarily spreads through academic cities, and within them, the housing estates with favourable locations in relation to the given university. For Polish cities, the phenomenon has so far been observed in Kraków (Zborowski 2005), Warsaw (Węcławowicz et al. 2003), Lublin (Rodzoś, Flaga 2010), Poznań (Kotus 2007; Ciesiółka 2010) and Łódź (Jakóbczyk-Gryszkiewicz 2013). Although this process does not have a permanent impact on population structure, because it involves temporary occupancy that is, not infrequently, unregistered ("unregistered tenancy"), it does produce tangible changes in the social landscape of housing estates ${ }^{8}$.

The empirical studies of the large housing estates in selected Polish cities, like Warsaw (Węcławowicz et al. 2003), Lublin (Rodzoś, Flaga 2010), Poznań (Ciesiółka 2010), Łódź (Marcińczak 2009) and Kraków (Zborowski 2005; Jerschina et al. 2012), show that, despite certain symptoms of housing filtration and outflow of the most affluent people with the most far-reaching housing aspirations, housing estates in these cities have not degraded socially. On the contrary, in many of the cities, large housing estates are still occupied by the middle class, thus rating highly within the socio-spatial structure of cities. Some housing estates, in particular those purported to be prevalently occupied by the intelligentsia under the previous political system (e.g., Prądnik Czerwony in Kraków, or Warsaw's Ursynów), boast a good position within the urban residential structure. This favourable social structure of Polish housing estates is also confirmed by measures describing population social structure other than educational background, such as the rate of unemployment or share of residents who are social aid beneficiaries - a proportion that relevant studies have found to be much lower in housing estates than in other urban areas defined as problem areas, and even lower than the average in those cities (e.g., the studies in Łódź - Szafrańska 2014, Lublin - Rodzoś, Flaga 2010, and Poznań - Ciesiółka 2010).

${ }^{8}$ The foregoing processes, triggered by the sale, inheritance, or private rental of flats within large housing estates, and leading to an inflow of younger groups of residents, are observed not only in Poland but also in the other post-socialist countries that have largely privatised such housing units, i.e., Hungary, the Czech Republic, Slovakia, and Bulgaria (see Stanilov 2007; Temelova et al. 2011; Kovács, Herfert 2012). 
The studies conducted in Kraków and Łódź demonstrate that the social status of large housing estates is frequently related to the time at which they were built. As a rule, where a population's social status is concerned, the newer housing estates compare favourably with the older ones ${ }^{9}$. What is more, this has been found not to derive exclusively from the age structure of housing-estate populations, but rather from the state-socialist era rules governing housing allocation, which, in certain decades, gave preference to certain social categories ${ }^{10}$.

However, the foregoing, favourable examples by no means attest to a more general rule that there are no downturns whatsoever in any of the post-socialist housing estates. Nevertheless, those analysing the issue of the potential social degradation of housing estates conclude that, with a few exceptions, this only looms over small fragments, or enclaves, of housing estates. This is because in the state-socialist era, the poorer classes within the socialist society were concentrated in single buildings or in small ensembles that tended to form quasi-slums, even in the communist era. Today, in the wake of the systemic transformation, certain housing estates with a relatively good and diversified social structure have begun to experience this problem, with enclaves of poverty and exclusion facilitated in this way. In Poland, this phenomenon is present, e.g., in Szczecin (Wojtkun 2004) and in Warsaw (Węcławowicz et al. 2003). These examples demonstrate that deep social segregation in the large housing estates in post-socialist Poland is only present on a microscale, and within small, specific estate areas.

The transformations of the social structure of the post-socialist housing estates are also informed by process of intensification of housing development. This process change the morphological structure of these residential areas and involves two types of development. The first one leads to an increase in the density of existing original housing resources built before 1990, through the development of greenfield sites. Most of these sites were designed originally to accommodate social and commercial infrastructure that was never built, due to the lack of sufficient financial resources and the rapid pace at which housing estates were built. The second type involves the building-up of areas on the outskirts of existing developments, which causes housing estates to spread. Both developments are stimulated by the opportunity to utilise existing utilities and infrastructure, which markedly reduces the costs of investment projects and makes these areas more attractive to developers.

New housing developments in Poland are typically single, multi-family buildings, rather than whole ensembles. They are characterised by a higher

\footnotetext{
${ }^{9}$ This situation is a result of a period of construction and the gradual improvement of standards imposed by central authorities (building and urban planning standards) during the four subsequent decades of state socialism.

${ }^{10}$ The results found by authors from other CEE countries confirmed these findings (see Kovács, Douglas 2004; Temelova et al. 2011).
} 
building standard and a different physiognomy that makes them stand out from the surrounding buildings (architectural details, richer colours, and diversified masses of buildings). New buildings frequently boast underground car parks, whilst their ground floors are occupied by shops and commercial services (Węcławowicz et al. 2003). Since the way in which new developments are located within the space of housing estates depends on the available free land, their sites are quite often random. However, in exceptional cases, they do help to create attractive new public spaces, e.g., by utilising peripheral development, unseen in those housing estates, to date, and creating multifunctional shopping (commercial) communications passageways. This solution has been applied successfully in, for example, Warsaw's Ursynów housing estate (Kozłowski 2010).

One social impact of the new developments appearing within existing housing estates is an inflow of people whose socio-economic status is higher than that of existing residents, hence the emergence, within such estates, of developments that represent enclaves of higher social status and greater housing prestige (Węcławowicz 2007; Szafrańska 2014). It follows that the high prices of flats in new buildings located within housing estates can constitute a barrier to their purchase. The price of $1 \mathrm{~m}^{2}$ of a new flat built within a large housing estate exceeds the average monthly wage in Polish cities ${ }^{11}$.

Some of the new residential buildings are built as gated communities within existing housing estates. Although not all new buildings are enclosed, the process of separation, i.e., surrounding such buildings with fences to separate them from the other local residents, is not infrequent in housing estates located in formerly socialist countries, though its scale is often varied (Matlovič et al. 2001). In Poland, the overall number of gated communities, including those within existing housing estates, is the highest in Warsaw. Interestingly, their locations within housing estates are not greatly affected by the current reputation of these housing estates. Research conducted in Warsaw demonstrates that life in a gated enclave is equally attractive in reputable Ursynów as in the less reputable, working-class housing estate of Wrzeciono (Węcławowicz et al. 2003). Thus, the paradox of gated communities being built within existing housing estates in post-socialist cities lies in the fact that such housing estates are generally safe, meaning that there is no good reason for their residents to separate themselves from the surroundings. The negative consequences of the construction of enclosed housing enclaves within housing estates include the appropriation of public spaces and disruption of their continuity, in both the physical dimension (the erection of barriers that prevent free movement) and the cultural (symbolic) dimension. This entails the processes of social segregation and separation within housing estates. Nevertheless, it is

${ }^{11}$ At the end of 2016 the average monthly salary was in Łódź PLN 4,200 gross, while the price of one square meter of a new apartment exceeded PLN 4,500. 
doubtless that the new housing - whether fenced or open - built within housing estates brings about an inflow of a younger, better-educated population of higher economic status and, consequently, helps to improve the social structure.

\section{Conclusions}

The presented research has shown that the main social and demographic transformation that have been taking place within Polish large housing estates since 1990, as discussed in this study, include the following phenomena:

- population decline ad residents' ageing, which depended on the period of their construction;

- the increasing number of one-person households, the decrease in the percentage of working people and the increase in level of education;

- maintaining a relatively high social status of the inhabitants, that contradicts the social degradation of these estates predicted in the 1990s;

- "studentification", which leads to rejuvenation of the demographic structure, but also to the high rotation of residents;

- an increase in the socio-spatial diversification of large housing estates that resulted from intensification of housing development, and the inflow of new better-off residents.

The identified phenomena occur in the majority of the large housing estates in Poland, but their frequency and extent differ between cities and individual estates. The investigation of literature and own previous author's research showed that these processes were determined by a number of mutually dependent factors, both endogenous, depending on the particular character of individual estates and their communities, and exogenous, external to these estates (operating both at the local and national level).

The socio-demographic processes listed above resulted from natural movement and migrations. However, some of them are not specific for large housing estates, because they occur in other urban areas in post-socialist cities and are associated with wider demographic trends and socio-cultural changes (i.e. changes in family life patterns and lifestyle changes). The other processes which were accompanied to examined changes e.g. the appearance of new housing buildings and turnover of flats on the secondary market were determined by political changes and market processes (especially the privatization and return of the housing market) which took place after the collapse of state socialism.

Summing up, despite the fact that over twenty five years have passed since the fall of the socialist system, the large housing estates in Poland are not problem areas and are not treated as such by the inhabitants, the city authorities, or the central authorities. The relatively good social status of the inhabitants is not decreasing, despite the outflow of the more affluent residents who have higher 
aspirations as regards the housing conditions. Living in large housing estates is still common in Polish cities and, consequently, is not seen as socially degrading.

As can be expected, the fact that large housing estates in post-socialist Polish cities do not degrade as much as their counterparts in Western Europe and still are attractive as a place of residence for people who belong to post-socialist middle class results above all from (Szafrańska 2016):

- enormous scale of those housing estates and their share in the housing resources of post-socialist cities reaching 30-40\%, which makes them common and considered as the "typical housing standard";

- housing deficiency carried over from the times of the former political system and preserved after 1990, though today its nature is not structural (as was under the previous regime) but economic;

- far-reaching privatisation of housing resources within housing estates, in some countries in excess of $90 \%$ of housing units, which factor reduces migration mobility and increases attachment to both the flat and the housing estate, and consequently improves public perception of them and enhances residential stability;

- structure of the incomes of post-socialist cities' residents and unfavourable ratio of the prices of new flats to the average income, which still prevents most average-income households from fulfilling their housing aspirations, in as much as it increases their residential stability;

- still relatively good living conditions offered by this residential form, especially in comparison with the old, low standard housing substance found in many cities (mainly as a result of underinvestment and lack of renovation works in the central areas of cities during the socialist period);

- relatively good and continuously improving furnishing of estates with shopping, service and social infrastructure; a large amount of greenery, especially as regards the densely built-up areas, often devoid of greenery, as well as good transport accessibility of many estates;

- relatively weak spatial mobility, established in the previous political system; considerable lack of migration and a sense of belonging; in effect - considerable residential stabilization;

- strongly limited during the socialist period and still modest aspirations of post-socialist cities' residents as regards their place of living in comparison with the inhabitants of other countries, as well as international standards;

- a sense of the lack of choice, caused by the socio-economic situation of the post-socialist cities inhabitants and the situation on the real estate market and the unfavorable relation between salaries and the prices of flats, which create a financial barrier, making it impossible for many households to satisfy their housing needs. 
Referencing the findings of the present study to the concepts of housing environment transformations described in world literature and used to investigate the transformations of large housing estates in West European cities, it can be stated that in the case of housing estates in post-socialist cities no, or very few, observations (in very few housing estates or their fragments) have been made of the phenomenon referred to as "spiral of decline" or "large housing estate syndrome" typical for this urban form in Western Europe.

Also, compared with many West European cities, the scale of filtration processes resulting from the outflow of high-status residents is much smaller. Actually, migrations out of housing estates are informed not so much by degradation of large housing estates, as by the arrival of new and more attractive residential areas that were not present in socialist cities, as well as the opportunity to satisfy individual housing needs outside the housing construction system subsidised by the state, as mortgage credits only became available after the system transformation. Hence, an important role in this process was played by the rather obvious, given the situation, growth of housing aspirations, strongly suppressed under the previous regime, and the natural technical and moral wear and tear of housing estate housing facilities resulting from their life cycle. Therefore, filtration processes within large housing estates are evolutionary in nature and fully governed by the natural process of certain housing resources becoming worn-out and obsolete, not by mass exodus of residents, as was predicted.

It appears, therefore, that the conditions prevailing under the previous political and economic system (which shaped a totally different social composition of housing estate residents within the same urban form) have combined with the transformation process itself (of fast pace and overlapping with global processes) to represent a unique legacy that determines the transformations taking place on the large housing estates of cities in formerly-communist countries, and thus distinguishes these from the processes that have been ongoing in Western European cities.

\section{Bibliography}

Basista A., 2001, Betonowe dziedzictwo, Wydawnictwo Naukowe PWN, Warszawa.

Ciesiółka P., 2010, Rehabilitacja zabudowy blokowej na przykładzie osiedla Jana III Sobieskiego w Poznaniu, [in:] Jażdżewska I. (ed.), Osiedla blokowe w strukturze przestrzennej miast, XXIII Konwersatorium Wiedzy o Mieście, Wydawnictwo Uniwersytetu Łódzkiego, Łódź: 89-100.

Coudroy de Lille L., 2000, Jak dalece można porównywać miasta europejskie? Refleksje nad procesami i pojęciami na przyktadzie osiedli mieszkaniowych we Francji i w Polsce, [in:] Jażdżewska I. (ed.), Miasto postsocjalistyczne-organizacja przestrzeni miejskiej i jej przemiany, XIII Konwersatorium Wiedzy o Mieście, Wydawnictwo Uniwersytetu Łódzkiego, Łódź: 99-112. 
Czepczyński M., 1999, Rozwój i upadek koncepcji osiedli blokowych, „Biuletyn KPZK PAN", 190: 49-67.

Dekker K., Halls S., van Kempen R., Tosics I., 2005, Restructuring large housing estates in European cities: an introduction, [in:] van Kempen R., Dekker K., Hall S., Tosics I. (eds.), Restructuring large housing estates in Europe, Policy Press, Bristol, UK: 1-17.

Enyedi G., 1998, Transformation in Central European postsocialist cities, [in:] Enyedi G. (ed.), Social change and urban restructuring in Central Europe, Akademiai Kiadó, Budapest: 9-34.

Éróss A., 2013, Past and Present of Large Housing Estates in Visegrad Countries and Armenia, „Hungarian Geographical Bulletin”, 62(1), Hungarian Academy of Science: 77-82.

Gorczyca K., 2009, Wielkie osiedla mieszkaniowe - diagnoza stanu obecnego. Podejmowane działania rewitalizacyjne, [in:] Jarczewski W. (ed.), Przestrzenne aspekty rewitalizacji, Instytut Rozwoju Miast, Kraków: 89-123.

Gorczyca K., 2016, The social transformation of large housing estates in Poland at the turn of the $21^{\text {st }}$ century, ,Sociologicky časopis/Czech Sociological Review”, 52 (6): 861-892.

Górczyńska M., 2008, Percepcja $i$ waloryzacja osiedla mieszkaniowego (na podstawie badań prowadzonych $w$ Warszawie $w$ ramach projektu RESTATE), „Przegląd Geograficzny", 2, IGIPZ PAN: 267-286.

Jakóbczyk-Gryszkiewicz J., 2013, Procesy studentyfikacji w Łodzi, [in:] Jakóbczyk-Gryszkiewicz J. (ed.), Procesy gentryfikacji, cz. II, XXVI Konwersatorium Wiedzy o Mieście, Uniwersytet Łódzki, Łódź: 95-107.

Jałowiecki B., 1995, Miasto polskie - między utopia a rzeczywistościa, [in:] Starosta P. (ed.), Zbiorowości terytorialne $i$ więzi społeczne, Wydawnictwo Uniwersytetu Łódzkiego, Łódź: 36-43.

Jarosz D., 2010, Mieszkanie się należy... Studium z peerelowskich praktyk społecznych, Oficyna Wydawnicza Aspra JR, Warszawa.

Jencks Ch., 1987, Ruch nowoczesny w architekturze, Wydawnictwa Artystyczne i Filmowe, Warszawa.

Jerschina J., Lesińska E., Pytliński Ł., Siwek H., 2012, Badania poczucia bezpieczeństwa mieszkańców Prądnika Czerwonego w Krakowie, [in:] Czapska J. (ed.), Zapobieganie przestępczości przez kształtowanie przestrzeni, Wydawnictwo Uniwersytetu Jagiellońskiego, Kraków: 201-247.

Kabisch S., Grossmann K., 2013, Challenges for large housing estates in light of population decline and ageing. Results of a long-term survey in East Germany, „Habitat International", 39: 232-239.

Kiciński A., 2004, Poland. A future for the 'blokowisko'?, [in:] Turkington R., van Kempen R., Wassenberg F. (eds.), High-rise housing in Europe. Current trends and future prospects, Delft University Press, Delft: 187-202.

Knorr-Siedow T., 1996, Present and future outlook for large housing estates, http://www. eaue.de/Housing/housfut/htm (accessed on: 20.02.2014).

Kotus J., 2007, Natura wielkomiejskich sasiedztw, Wydawnictwo Uniwersytetu Adama Mickiewicza, Poznań. 
Kovács Z., Douglas M., 2004, Hungary. From socialist ideology to market reality, [in:] Turkington R., van Kempen R., Wassenberg F. (eds.), High-rise housing in Europe. Current trends and future prospects, Delft University Press, Delft: 231-248.

Kovács Z., Herfert G., 2012, Development pathways of large housing estates in post-socialist cities: an international comparison, „Housing Studies”, 27 (3): 324-342.

Kozłowski S., 2010, Przeszkody i bariery na drodze humanizacji osiedli, [in:] Jażdżewska I. (ed.), Osiedla blokowe w strukturze przestrzennej miast, XXIII Konwersatorium Wiedzy o Mieście, Wydawnictwo Uniwersytetu Łódzkiego, Łódź: 73-87.

Large housing estates in Poland. Territorial enclosure, privatisation of the public space, RESATE, Conference for researchers and policymakers, 19-21.05.2005, Ljubljana, Slovenia, http://restate.geo.uu.nl/conference/posterexhibition/Poland1.pdf (accessed on: 18.08.2013).

Lewicka M., 2004, Identyfikacja z miejscem zamieszkania mieszkańców Warszawy: determinanty i konsekwencje, [in:] Grzelak J., Zarycki T. (eds.), Społeczna mapa Warszawy, Wydawnictwo Scholar, Warszawa: 273-315.

Marcińczak S., 2009, Przemiany struktury społeczno-przestrzennej Łodzi w latach 19882005, Wydawnictwo Uniwersytetu Łódzkiego, Łódź.

Matlovič R., Ira V., Sýkora L., Szczyrba Z., 2001, Procesy transformacyjne struktury przestrzennej miast postkomunistycznych na przykładzie Pragi, Bratysławy, Ołomuńca oraz Preszowa, [in:] Jażdżewska I. (ed.), Miasto postsocjalistyczne-organizacja przestrzeni miejskiej i jej przemiany, XIV Konwersatorium Wiedzy o Mieście, Wydawnictwo Uniwersytetu Łódzkiego, Łódź: 243-252.

Musterd S., van Kempen R., 2005, Large-scale housing estates in European cities: opinions of residents on recent developments. RESTATE, Utrecht University, Utrecht.

Nowakowski M., 2013, Sto lat planowania przestrzeni polskich miast (1910-2010), Oficyna Naukowa, Warszawa.

Prak N.L., Premius H., 1986, A model for the analysis of the decline of postwar housing, „The International Journal of Urban and Regional Research”, 10: 1-7.

Rembarz G., 2010, Rola przestrzeni publicznej $w$ odnowie i kształtowaniu miejskiego środowiska mieszkaniowego, [in:] Lorens P., Martyniuk-Pęczek J. (eds.), Zarządzanie rozwojem przestrzennym miast, Urbanista, Gdańsk: 138-156.

RębowskaA., 2000, Rehabilitacja blokowisk, [in:] Ziobrowski Z., Ptaszycka-Jackowska D., Rębowska A., Geissler A. (eds.), Odnowa miast. Rewitalizacja, rehabilitacja, restrukturyzacja, Instytut Gospodarki Przestrzennej i Komunalnej, Kraków: 85-105.

Rębowska A., Jeżak J., Rydzik W., Węgłowski M., 2006, Strategie rehabilitacji „,blokowisk”, Instytut Rozwoju Miast, Kraków.

Rodzoś J., Flaga M., 2010, Nowa sytuacja społeczna starych osiedli mieszkaniowych na przyktadzie osiedla im A. Mickiewicza w Lublinie, [in:] Jażdżewska I. (ed.), Osiedla blokowe w strukturze przestrzennej miast, XXIII Konwersatorium Wiedzy o Mieście, Wydawnictwo Uniwersytetu Łódzkiego, Łódź: 101-118.

Rykiel Z., 1999, Przemiany struktury społeczno-przestrzennej miasta polskiego a świadomość terytorialna jego mieszkańców, „Prace Geograficzne”, 170, IGiPZ PAN.

Sagan I., 2000, Miasto. Scena konfliktów i współpracy, Wydawnictwo Uniwersytetu Gdańskiego, Gdańsk. 
Smith D.P., 2002, Patterns and processes of studentification in Leeds, „Regional Review”, 12(1): 14-16.

Stanilov K., 2007, Housing trends in Central and Eastern European cities during and after the period of transition, [in:] Stanilov K. (ed.), The post-socialist city. Urban form and space transformations in Central and Eastern Europe after socialism, Series: „Geo Journal Library”, 92, Springer, Dorgdrecht: 173-190.

Sýkora L., 2009, Post-socialist cities, [w:] Kitchin R., Thrift N. (eds.), International Encyclopedia of Human Geography, 8, Elsevier, Oxford: 387-395.

Szafrańska E., 2013, Large housing estates in post-socialist Poland as a housing policy challenge, „European Spatial Research and Policy”, 20 (1): 119-129.

Szafrańska E., 2014, Transformations of large housing estates in post-socialist cities: The case of Łódź, Poland, „Geographia Polonica”, 87 (1): 77-94.

Szafrańska E., 2015, Transformations of large housing estates in Central and Eastern Europe after the collapse of Communism, „Geographia Polonica”, 88 (4): 621-648.

Szafrańska E., 2016, Wielkie osiedla mieszkaniowe w mieście postsocjalistycznym. Geneza rozwój, przemiany, percepcja, Wydawnictwo Uniwersytetu Łódzkiego, Łódź.

Szelényi I., 1996, Cities under socialism - and after, [in:] Andrusz G., Harloe M., Szelényi I. (eds.), Cities after socialism. Urban and regional change and conflict in post-socialist societies, Blackwell Publishers, Oxford: 286-317.

Temelová J., Novák J., Ouředniček M., Puldová P., 2011, Housing estates in the Czech Republic after socialism: Various trajectories and inner differentiation, „Urban Studies", 48(9): 1811-1834.

Tokajuk A., 2007, Zespoły mieszkaniowe z lat 1945-1970, Wydawnictwo Politechniki Białostockiej, Białystok.

Wassenberg F., Turkington R., van Kempen R., 2004, Prospects for high-rise housing estates, [in:] Turkington R., van Kempen R., Wassenberg F. (eds.), High-rise housing in Europe: current trends and future prospects, Delft University Press, Delft: 265-280.

Wassenberg F., 2013, Large housing estates: Ideas, rise, fall and recovery, „The Bijlmermeer and Beyond”, Serie: „Sustainable Urban Areas”, 48, Delft University Press, Delft.

Węcławowicz G., 2007, Geografia społeczna miast, Wydawnictwo Naukowe PWN, Warszawa.

Węcławowicz G., Kozłowski S., Bajek R., 2003, Large housing estates in Poland: overview of developments and problems in Warsaw. RESTATE, Utrecht University, Utrecht.

Węcławowicz G., Guszcza A., Kozłowski S., Bielawska A., Adamiak A., Krasowska M., Fader A., Bierzyński A., 2005, Large housing estates in Poland: opinions of residents on recent developments. RESTATE, Utrecht University, Utrecht.

Wiest K., 2011, Large-scale housing estates in Central and East European cities: between residential preferences and local housing market differences, „Housing: Theory and Society", 28 (4): 410-431.

Wojtkun G., 2004, Osiedle mieszkaniowe w strukturze miasta XX wieku, Wydawnictwo Politechniki Szczecińskiej, Szczecin.

Wojtkun G., 2008, Wielorodzinne budownictwo mieszkaniowe w Polsce. W cieniu wielkiej plyty, „Przestrzeń i Forma”, 10: 175-194. 
Zborowski A., 2005, Przemiany struktury społeczno-przestrzennej regionu miejskiego $w$ okresie realnego socjalizmu i transformacji ustrojowej (na przykładzie Krakowa), Instytut Geografii i Gospodarki Przestrzennej Uniwersytetu Jagiellońskiego, Kraków.

\section{ZMIANY W STRUKTURZE SPOLECZNEJ I DEMOGRAFICZNEJ WIELKICH OSIEDLI MIESZKANIOWYCH W POSTSOCJALISTYCZNEJ POLSCE I ICH GLÓWNE DETERMINANTY}

Zarys treści: Wielkie prefabrykowane osiedla mieszkaniowe powstawały w całej Europie, jednakże czynniki polityczne i ideologiczne przyczyniły się do tego, że na największą skalę rozwinęły się w krajach realnego socjalizmu. Obecnie nadal stanowią one około 30-40\% zasobów mieszkaniowych w tej części Europy. W artykule omówiono przemiany wielkich osiedli mieszkaniowych, jakie zaszły w Polsce w ciągu 25 lat po upadku komunizmu. Głównym celem badań była odpowiedź na następujące pytania: (1) Jak zmieniły się struktury społeczne i demograficzne dużych osiedli mieszkaniowych w Polsce od czasu upadku socjalizmu? (2) Jakie są główne determinanty tych procesów? (3) Czy procesy zachodzące w tych osiedlach odzwierciedlają negatywne zjawiska degradacji społecznej obserwowane w wielu krajach Europy Zachodniej? Podstawą opracowania był przegląd dostępnej literatury dotyczącej przekształceń wielkich osiedli mieszkaniowych w kilku dużych miastach Polski oraz wyniki badań własnych przeprowadzonych w jednym z największych miast w kraju, jakim jest Łódź.

Słowa kluczowe: Wielkie osiedla mieszkaniowe, miasto postsocjalistyczne, zmiany społeczne i demograficzne, kraje CEE, Polska.

Ewa Szafrańska, PhD Assoc. Prof. Institute of Urban Geography and Tourism Studies

Faculty of Geographical Sciences

University of Łódź e-mail: ewa.szafranska@geo.uni.lodz.pl 